\title{
Effects of Potentilla Fulgens as Prophylactic Agent in Intestinal Ischemia Reperfusion Injury
}

\author{
Efectos de Potentilla fulgens como Agente Profiláctico \\ en la Lesión por Isquemia-Reperfusión Intestinal
}

\author{
Nurettin Tunç*; Mahmut Tas**; Mücahit Görük ${ }^{* * *}$; Günsel Kirman ${ }^{* * * *}$ \& Engin Deveci****
}

TUNC, N.; TAS, S.; GÖRÜK, M.; KIRMAN, G. \& DEVECI, E. Effects of Potentilla fulgens as prophylactic agent in intestinal ischemia reperfusion injury. Int. J. Morphol., 33(4):1313-1318, 2015.

SUMMARY: The purpose of this study, ischemia reperfusion injury in rats, Potentilla fulgens is to investigate the protective effects. Wistar albino rats $(\mathrm{n}=30)$ weighing 180-220 $\mathrm{g}$ were used in the experiment. Group 1 animals underwent sham laparotomy without ischemiareperfusion injury. Group 2 animals underwent laparotomy and occlusion of superior mesenteric arteries for 30 min followed by 20 min of reperfusion without pretreatment. The Potentilla fulgens group received $400 \mathrm{mg} / \mathrm{kg} /$ day Potentilla fulgens intraperitoneally 5 days before Ischemia-reperfusion injury. There was a significant difference between the group with ischemia-reperfusion group Potentilla fulgens ( $<<0.0001$ ). In statistical analysis of the MDA level, data were obtained after a respective measurement in all groups. Potentilla fulgens group with ischemia-reperfusion group was a significant decrease in MDA $(\mathrm{p}<0.001)$. In the period after ischemia-reperfusion, marked PCNA immunoreactivities were observed in the nuclei of crypt and villus cell. In ischemia reperfusion group, the number of PCNA immunoreactivity is quite advanced and they extended throughout the middle part of the intestine folds. The number of TUNEL-positive nuclei were also developed. In ischemia-reperfusion plus $P$. fulgens group, the intestinal epithelium with only a few PCNA immunoreactive nuclei. TUNEL positive nuclei were noted in the gut lumen and mucosal close differentiated goblet cells. We showed that Potentilla fulgens extract significantly prevented mucosal lesions caused by intestinal ischemia-reperfusion.

KEY WORDS: Intestinal ischemia; Proliferating Cell Nuclear Antigen (PCNA); Rat; Tunnel method.

\section{INTRODUCTION}

Intestinal 1schemia-reperfusion (I/R) injury is essentially an inflammatory response process and is a significant problem in abdominal aortic aneurysm surgery, small bowel transplantation, cardiopulmonary bypass, strangulated hernias and neonatal necrotizing enterocolitis (Collard \& Gelman, 2001). Ischemia-reperfusion injury (IRI) can be attributed to many factors such as the release of free oxygen radicals and consecutive lipid peroxidation, cell death by apoptosis or necrosis, inflammatory cytokines, and damage to the microvasculature (Granger et al., 1981; Bodwell, 1989; Carden \& Granger, 2000; Mallick et al., 2004). Although the definitive pathophysiology regarding intestinal I/R injury still remains obscure, it is generally believed that oxidative stress mediators such as Reactive Oxygen Species (ROS), polymorphonuclear neutrophils and Nitric Oxide (NO) are suggested to play an important role (Murry et al., 1986). Potentilla fulgens Lodd. is an alpine plant of Western Himalayas that is consumed in all parts of the world for its promising medicinal properties. Pharmacologically, the aerial and root portions of the plant are reported to have antioxidant (in in vitro models) (Kaul et al., 2010), antitumour (Syiem et al., 2003), hypoglycemic and antihyperglycemic activities (Syiem et al., 2009). Recently gastroprotective activity of ethanolic root extract of P. fulgens has also been reported (Laloo et al., 2013). The general signs and symptoms of toxicity, food water intake and mortality rates of animals were observed for $72 \mathrm{~h}$ posttreatment. From these observations, LD50 was calculated using SPSS software (Tangpu et al., 2014). Proliferating Cell Nuclear Antigen (PCNA) is a significant cell-cycle regulated nuclear protein for DNA-polymerase, the PCNA-labeled nuclei had been shown to identify cells in the late G1 and early $\mathrm{S}$ phases of the cell cycle, as well as cells undergoing DNA repair (Chen et al., 2005). The purpose of this study, ischemia reperfusion injury in rats, Potentilla fulgens is to investigate the protective effect.

* Department of Gastroenterology, Firat of University, Faculty of Medicine, Elazıg, Turkey.

** Department of Emergency, Gazi Yas sargil Hospital, Diyarbakır, Turkey.

**** Department of Internal Diseases, Gazi Yas, argil Hospital, Diyarbakır, Turkey.

**** Department of Histology and Embryology, Faculty of Medicine, Dicle of University, Diyarbakır, Turkey. 


\section{MATERIAL AND METHOD}

Wistar albino rats $(\mathrm{n}=30)$ weighing $180-220 \mathrm{~g}$ were used in the experiment. The under rats were kept under specific pathogen-free conditions with 12-hour light/dark cysles and were given food and water ad libitium. All animal experiments were performed in accordance with our institutional guidelines after obtaining the permission from the laboratory animal committee. Anesthesia was induced by intramuscular injection of $25 \mathrm{mg} / \mathrm{kg}$ Ketamine hydrocloride +Xylazine.

Animals were randomly divided into 3 groups of 10 rats each. The sham group underwent sham laparotomy without Ischemia-Reperfusion injury. The IschemiaReperfusion injury group served as the control group. These animals laparotomy and occlusion of superior mesenteric arteries for $30 \mathrm{~min}$ followed by $20 \mathrm{~min}$ of reperfusion without pretreatment. The Potentilla fulgens group received $400 \mathrm{mg} /$ $\mathrm{kg} / \mathrm{day}$ Potentilla fulgens intraperitoneally 5 day before ischemia-reperfusion injury. Ten to fifteen minutes after general anesthesia,the peritoneum of each rat was opened for $30 \mathrm{~min}$. The arteria mesenterica superior was clamped to create an ischemia,followed by 20 were obtained for MDA and histopathological examination. The samples of intestine tissue were fixed immediately formaldehyde $10 \%$ embedded in paraffine wax, sectioned serially at 4-6 $\mu \mathrm{m}$ and stained with hematoxylene-Eosin (H-E). One section from each rat was graded blindly and semi-quantitative, histological evaluations were graded from 0 to 5 by a single observer, according to the index of Park et al. (1990) (Table I).

At reperfusion destruction, an MDA level that indicated the lipid peroxidation was calculated as nanomole per tester's $1 \mathrm{~g}$ of duodenum tissue (Tangpu et al.). These tissue samples were homogenized after $0.5 \mathrm{ml}$, of $10 \%$ and $4 \mathrm{ml}$ of $5 \%$ trichloroasetic acid were applied to them(allreagents and compounds were obtained from Sigma Chemical Co, St. Louis, Missouri, USA). They were centrifuged at $4000 \mathrm{rpm}$. A $1 \mathrm{ml}$ sample is taken andmixed with $1 \mathrm{ml}$ of $67 \%$ thiobarbituric acid and heated for $10 \mathrm{~min}$. The absorbance value was read with 532-nm spectrometry, and its nanomole value for $1 \mathrm{~g}$ tissue was found.
Immunohistochemical staining: The tissues were put into a formalin solution for fixation and then embedded in paraffin wax. Then they were cut into 4-6 mm sections on positively charged glass slides. Sections were deparaffinized with xylene, followed by immersion in graded acohol for dehydration and incubation with EDTA $(\mathrm{pH}=8.0$, Merck, Germany) for $5+4+3$ minutes in a microwave oven (750 Watt) for antigen retrieval. Next, sections were incubated for 20 min in $3 \% \mathrm{H}_{2} \mathrm{O}_{2}$ /Methanol to block endogenous peroxidase activity, then rinsed in phosphate-buffered saline (PBS) for $5 \mathrm{~min}$ three times. The sections were later incubated with a blocking solution (normal goat serum, Invitrogen, Carlsbad, CA). Slides were then incubated overnight with primary antibodies, Proliferating Cell Nuclear Antigen (PCNA) monoclonal antibody from Labvision Inc., Fremont, CA, USA. After washing in PBS, the sections were treated with labeledstreptavidin kits (Invitrogen, Carlsbad, CA). The reaction was visualized by incubating the sections for $7 \mathrm{~min}$ in a $0.1 \%$ 3,3 diaminobenzidine and $0.02 \%$ hydrogen peroxide solution (DAB substrate kit, Invitrogen, Carlsbad CA). Finally, the sections were counterstained with Hematoxylin (Sigma) and covered. Immunohistochemistry positive staining was defined as the presence of a brown color detection chromogen (DAB) on the edge of the hematoxylin-stained cell nucleus distributed within the cytoplasm or plasma membrane of the cells and assessed by light microscope.

Tunnel tecnique: Anti-proliferating cell nuclear antigen (PCNA) antibody was employed for detection of the proliferation rate of enterocytes. Sections taken to distilled water were then washed in PBS $2 \times 5$ min sections was kept in freshly prepared permeabilisation solution $(0.1 \%$ Triton $\mathrm{X}-100$ in $0.1 \%$ sodium citrate) $8 \mathrm{~min}$ on ice. then washed in PBS 2x5 min and Added TUNEL Mixture (diluted 1:1 with TUNEL Dilution Buffer) on sections in the dark in humidified chamber for 1 at $37^{\circ} \mathrm{C}$. washed in PBS $2 \times 5 \mathrm{~min}$, As a substrate solution, Fast Red (Roche) is applied on sections. Sections were counterstained with Hematoxyline, Mounted with Kaiser's Glycerol Gelatine (Roche).

Table I. Scala for ischemic lesions (Histologic grading).

\begin{tabular}{ll}
\hline Grade 0 & Normal morphology \\
Grade 1 & Sub-epithelial edema and partial separation of apical cells \\
Grade 2 & Moderate lifting of enter ocytes from the tips of the villi \\
Grade 3 & Lifting of enterocytes from both the tips and the sides of the villi (including superficial crypts) \\
Grade 4 & Partial mucosal necrosis of the lamina propria \\
Grade 5 & Total mucosal necrosis
\end{tabular}




\section{RESULTS}

In statistical analysis of histopathological findings, the data was obtained after grading assesment of the mucosal damage in all groups. The nonparametric Kruskal Wallis ANOVA procedure and a multiple comparison procedure based on the Tukey test has been used to analyse the histopathological scores $(\mathrm{p}<0.05)$ (Table II). In statistical analysis of MDA level, data was obtained after a respective measurement in all groups.

There was a significant difference between the group with ischemia-reperfusion group Potentilla fulgens $(\mathrm{p}<0.0001)$.

Potentilla fulgens group with ischemia-reperfusion group was a significant decrease in MDA ( $<<0.001)$. Intestinal segments from the rats in the sham group displayed a normal microscopic appearence. The mucosa contained intact villi, cypts and submucosa; muscular layers were unaffected (Fig. 1A). Histopathological examination of duodenal and jejunum border obtained after I/R, revealed histolopathological changes. These changes were represented desquamation and distortion of some villi epithelial sloughing and inflammatory cellular infiltration mainly polymorphonuclear cells, the tips of the villi and irregular loss of brush border in some areas and edema space in lamina propria region were observed. Dilatation and hemorrhage of blood capillaries, in connective tissue (Fig. 1B). Ischemiareperfusion + fulgens group showed that the villi and the crypts were almost similar to those of the control group. Peeling at the villi apex was observed. Overall, the villar structure was well preserved. Decreased capillary congestion and sparse inflamatory cell infiltration was noted. The crypts of Leiberkuhn appeared as invaginations of the mucosa between the bases of the villi. Proliferating cell nuclear antigen staining showed PCNA positive nuclei mostly distributing in the nuclei of crypt cells, In ischemia reperfusion group, the number of PCNA immunoreactivity is quite advanced and they extended throughout the middle part of the intestine folds; The number of TUNEL-positive nuclei were also developed.

In the period after ischemia-reperfusion, marked PCNA immunoreactivities were observed in the nuclei of crypt and villus cell. In ischemia reperfusion group, the number of PCNA immunoreactivity is quite advanced and they extended throughout the middle part of the intestine folds; In ischemia-reperfusion + fulgens group, the intestinal epithelium with only a few PCNA immunoreactive nuclei by TUNEL positive nuclei were noted in the gut lumen and mucosal close differentiated goblet cells.
Table II. The data of histopathological assessments according to Park et al. (1990)'s grading of the mucosal damage.

\begin{tabular}{cccc}
\hline $\begin{array}{c}\text { Indices } \\
\text { (Rat) } \\
\text { n=10 }\end{array}$ & $\begin{array}{c}\text { Sham } \\
\text { group }\end{array}$ & Ischemi-reperfusion & $\begin{array}{c}\text { Ischemi- } \\
\text { reperfusion }+ \\
\text { PotentillaFulgens } \\
\text { group }\end{array}$ \\
\hline 1 & 0 & 5 & 1 \\
2 & 0 & 4 & 1 \\
3 & 0 & 4 & 2 \\
4 & 0 & 4 & 1 \\
5 & 0 & 5 & 2 \\
6 & 0 & 3 & 1 \\
7 & 0 & 5 & 2 \\
8 & 0 & 4 & 2 \\
9 & 0 & 5 & 2 \\
10 & 0 & 5 & 2 \\
Mean & 0 & 4.3 & 1.6 \\
\hline
\end{tabular}

\section{DISCUSSION}

Intestinal ischemia-reperfusion can have significant effects in many clinical situations. Parks \& Granger (1986) reported that tissue lesions produced during reperfusion were greater than those produced during ischemia, in mesenteric $\mathrm{I} / \mathrm{R}$ in felines. $\mathrm{I} / \mathrm{R}$ can provoke complex interactions between the endothelium and different cell types, leading to microvascular injury, cellular necrosis and/or apoptosis (Massberg \& Messmer, 1998). Ischemia and reperfusion of the small intestine provoke the rupture of the mucosa barrier, bacterial translocation and the activation of inflammatory responses (João et al., 2004). Histological damage that occurs after intestinal I/R in the form of shortening of the villi length, loss of villus epithelium, dilatation and congestion of blood vessels, degeneration of epithelial cells with nuclear alterations and invasion by inflammatory cells were coincided with the results of the present work (Tunc et al., 2009). In Potentilla fulgens group, slightly breaking the apical and lateral surfaces of the villi, connective tissue beneath the epithelium were observed in a small number of inflammatory cell infiltration.Villi in the intestine fully protected, significant damage are not observed in the mucosa (Fig. 1C).

Immunohistochemistry with PCNA antibody and the TUNEL method have been widely used in fish species to demonstrate the renewal of enterocytes in studies ranging from experimental diet to environmental and toxicological assessments (Ferrando et al., 2005; Pohlenz et al., 2012). 


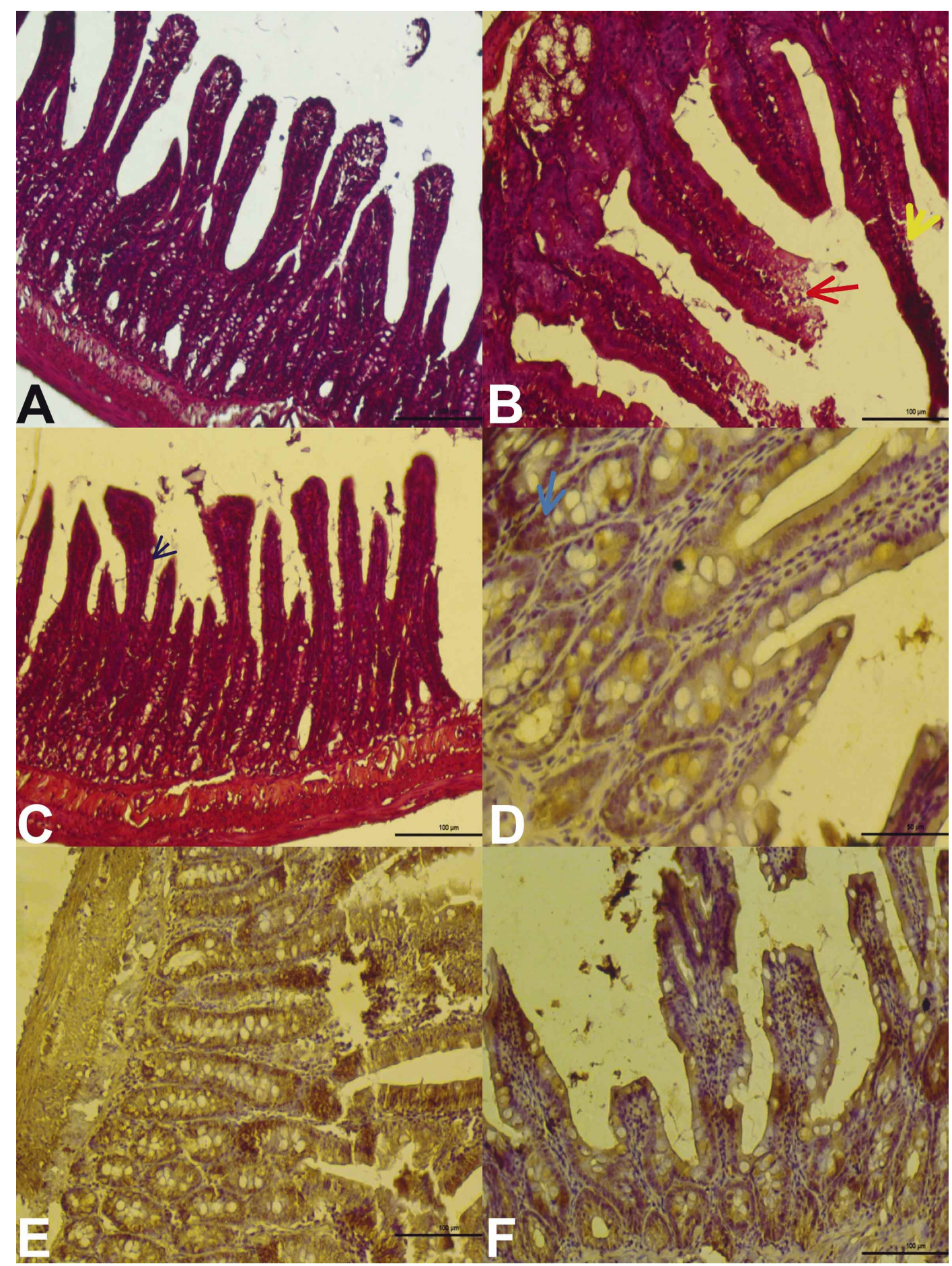

Fig. 1. A) Sham group, Normal appearance in intestinal mucosa (H-E staining, Bar $100 \mu \mathrm{m})$. B) Decrease and broken in villi structure (yellow arrow), edema and necrosis in subepithelial lamina propria (red arrow) (H-E staining, Bar $50 \mu \mathrm{m}$ ). C) Slight break in the apical and lateral surfaces of the villi, (arrow) a small number of inflammatory cell infiltration in the connective tissue beneath the epithelium (H-E staining, Bar $100 \mu \mathrm{m})$. D) Control group, PCNA positive nuclei in the crypt and glands region (PCNA immunostaining and hematoxylin stain, Bar $50 \mu \mathrm{m})$. E) Ischemia-reperfusion group the breakage of the villi and crypts in long, increased PCNA expression (PCNA immunostaining and hematoxylin stain, Bar $100 \mu \mathrm{m}$ ). F) I'schemia-reperfusion+Potentilla fulgens group, Intestinal epithelium and crypts in the regular distribution of positive cells (PCNA immunostaining and hematoxylin stain, Bar $100 \mu \mathrm{m})$. 


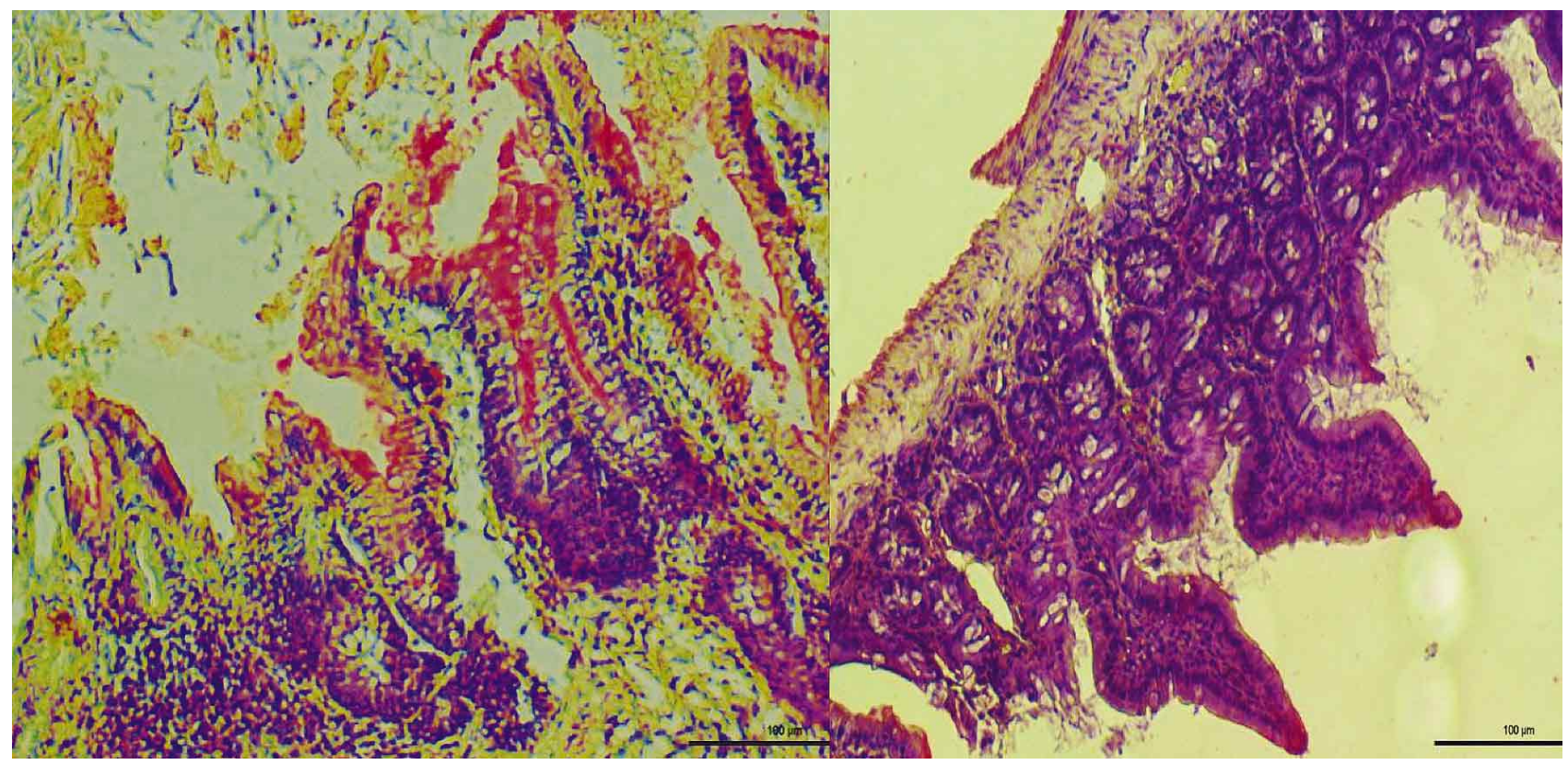

Fig. 2. A) Ischemia-reperfusion group A increase of apoptotic cells in intestinal epithelium and deep crypts (Tunnel method (PCNA), Hematoxylin stain, Bar $50 \mu \mathrm{m}$ ). B) Ischemia-reperfusion+Potentilla fulgens group A small number of apoptotic cells in the surface epithelium (Tunnel method (PCNA), Hematoxylin stain, Bar $50 \mu \mathrm{m}$ ).

Table III. The data of MDA levels of control and experimental groups of rats.

\begin{tabular}{lcc}
\hline $\begin{array}{c}\text { Indices } \\
\text { (Rat) } \\
\text { n= 10 }\end{array}$ & Ischemi-reperfusion & $\begin{array}{c}\text { Ischemi-reperfusion + } \\
\text { group }\end{array}$ \\
\hline 1 & $\begin{array}{c}\text { PotentillaFulgens } \\
\text { group }\end{array}$ \\
2 & 48 & 21 \\
3 & 46 & 19 \\
4 & 38 & 24 \\
5 & 49 & 19 \\
6 & 50 & 20 \\
7 & 52 & 23 \\
8 & 39 & 22 \\
9 & 40 & 21 \\
10 & 49 & 20 \\
Mean & 36 & 22 \\
\hline
\end{tabular}

This is in accordance with result of some investigators who reported non significant increase in the number of PCNA-positive cells in the section obtained after $240 \mathrm{~min}$ from reperfusion (Shima et al., 2006). Our study demonstrated that the expressing levels of PCNA after reperfusion were higher than the levels of control in both crypt and villus epithelial cells. These findings indicated that the repair process of small intestinal mucosa was initiated by $\mathrm{I} / \mathrm{R}$ and cellular regeneration continued for following reperfusion. A recent study also tested the acute toxicity of P. fulgens root extract and did not find any mortality or symptoms of toxicity in animals up to 4000 $\mathrm{mg} / \mathrm{kg}$ (Laloo et al.).

Laloo et al., have also reported that 200 and 400 $\mathrm{mg} / \mathrm{kg}$, p.o. dose of P. fulgens root ethanolic extract significantly inhibits ethanol and pyloric ligation-induced gastric ulcers due to its anti-secretory properties.

The small intestine is highly sensitive to ischemiareperfusion. It has been demonstrated that occlusion of the superior mesenteric artery followed by reperfusion can cause apoptosis in the intestinal epithelium (Noda et al., 1998). The improvement in the intestinal mucosa of Potentilla fulgens group,that we have a hyperplastic intestinal mucosa with a high proliferation of supported to increase the absorptive surface of adaptive responses. These results suggest that Potentilla fulgens treatment could inhibit cellular apoptosis of mucosal cells and induced cell proliferation to accelerate regeneration and repair of small intestinal mucosa after ischemia-reperfusion insult. Potentilla fulgens exerts a positive protective effect on the mucosal barrier and decreases the intestinal permeability. Its administration may be helpful in patients with a risk of intestinal ischemic disease. 
TUNC, N.; TAS, S.; GÖRÜK, M.; KIRMAN, G. \& DEVECI, E. Efectos de Potentilla fulgens como agente profiláctico en la lesión por isquemia-reperfusión intestinal. Int. J. Morphol., 33(4):1313-1318, 2015.

RESUMEN: El objetivo fue investigar los efectos protectores de Potentilla fulgens sobre la lesión por isquemia-reperfusión en ratas albinas Wistar ( $\mathrm{n}=30$ ) con un peso de $180 \mathrm{~g}$. En el grupo 1, los animales fueron sometidos a laparotomía simulada sin lesión por isquemia-reperfusión. En el Grupo 2, los animales fueron sometidos a laparotomía y oclusión de las arteria mesentérica superior durante $30 \mathrm{~min}$ seguido de $20 \mathrm{~min}$ de reperfusión sin pretratamiento. El grupo Potentilla fulgens recibió 400 $\mathrm{mg} / \mathrm{kg} / \mathrm{día}$ de $P$. fulgens por vía intraperitoneal 5 días antes de la lesión por isquemia-reperfusión. Hubo diferencias significativas entre el grupo de grupo con isquemiareperfusión y el tratado con Potentilla fulgens ( $\mathrm{p}<0,0001$ ). En el análisis estadístico del nivel de malondialdehído (MDA), los datos se obtuvieron después de una medición respectiva en todos los grupos. Los grupos Potentilla fulgens y con isquemia-reperfusión tuvieron una disminución significativade MDA ( $\mathrm{p}<0,0001)$. En el periodo después de la isquemia-reperfusión, se observó inmunorreactividad del marcador PCNA en los núcleos de las células de las criptas y vellosidades. En el grupo de isquemiareperfusión, la inmunoreactividad a PCNA fue bastante avanzada y se extendió a lo largo de la parte media de los plieges intestinales. También aumentó el número de núcleos positivos a TUNEL. En el grupo isquemia-reperfusión tratado con $P$. fulgens, el epitelio intestinal mostró pocos núcleos inmunorreactivos a PCNA; núcleos positivos a TUNEL se observaron en el lumen intestinal y la mucosa, cerca de las células caliciformes diferenciadas. Demostramos que el extracto de $P$. fulgens disminuye significativamente lesiones de la mucosa intestinal causadas por la isquemia-reperfusión

PALABRAS CLAVE: Isquemia intestinal; Antígeno nuclear de proliferación celular (PCNA); Rata; Método de tunel.

\section{REFERENCES}

Bodwell, W. Ischemia, reperfusion, and reperfusion injury: role of oxygen free radicals and oxygen free radical scavengers. J. Cardiovasc. Nurs., 4(1):2532, 1989 .

Carden, D. L. \& Granger, D. N. Pathophysiology of ischaemia-reperfusion injury. J. Pathol., 190(3):255-66, 2000

Chen, W.; Fu, X. B.; Ge, S. L.; Sun, T. Z.; Li, W. J. \& Shen, Z. Y. Acid fibroblast growth factor reduces rat intestinal mucosal damage caused by ischemiareperfusion insult. World J. Gastroenterol., 11(41):6477-82, 2005.

Collard, C. D. \& Gelman, S. Pathophysiology, clinical manifestations, and prevention of ischemia-reperfusion injury. Anesthesiology, 94(6):1133-8, 2001.

Ferrando, S.; Ferrando, T.; Girosi, L.; Mauceri, A.; Fasulo, S. \& Tagliafierro, G. Apoptosis, cell proliferation and serotonin immunoreactivity in gut of Liza aurata from natural heavy metal polluted environments: preliminary observations. Eur. J. Histochem., 49(4):331-40, 2005.

Granger, D. N.; Rutili, G. \& McCord, J. M. Superoxide radicals in feline intestinal ischemia. Gastroenterology, 81(1):22-9, 1981.

João, A. S.; Alencar, S. S. S.; Medeiros, A. C.; Diniz, S. O. F.; Cardoso, V. N. \& Brandt, C. T. Translocation of $99 \mathrm{mTc}$ labelled bacteria after intestinal ischemia and reperfusion. Acta Cir. Bras., 19(4):328-33, 2004.

Kaul, K.; Jaitak, V. \& Kaul, V. K. Review on pharmaceutical properties and conservation measures of Potentilla fulgens Wall. Ex Hook. - A medicinal endangered herb of higher Himalaya. Indian J. Nat. Prod. Resour., 2(3):298306, 2010.

Laloo, D.; Prasad, S. K.; Krishnamurthy, S. \& Hemalatha, S. Gastroprotective activity of ethanolic root extract of Potentilla fulgens Wall. ex Hook. $J$. Ethnopharmacol., 146(2):505-14, 2013.

Mallick, I. H.; Yang, W.; Winslet, M. C. \& Seifalian, A. M. Ischemia-reperfusion injury of the intestine and protective strategies against injury. Dig. Dis. Sci., 49(9):1359-77, 2004.

Massberg, S. \& Messmer, K. The nature of ischemia/reperfusion injury. Transplant. Proc., 30(8):4217-23, 1998.

Murry, C. E.; Jennings, R. B. \& Reimer, K. A. Preconditioning with ischemia: a delay of lethal cell injury in ischemic myocardium. Circulation, 74(5):112436, 1986.
Noda, T.; Iwakiri, R.; Fujimoto, K.; Matsuo, S. \& Aw, T. Y. Programmed cell death induced by ischemia-reperfusion in rat intestinal mucosa. Am. J. Physiol., 274(2 Pt. 1):G270-6, 1998

Park, P. O.; Haglund, U.; Bulkley, G. B. \& Fält, K. The sequence of development of intestinal tissue injury after strangulation ischemia and reperfusion. Surgery, 107(5):574-80, 1990

Parks, D. A. \& Granger, D. N. Contributions of ischemia and reperfusion to mucosal lesion formation. Am. J. Physiol., 250(6 Pt. 1):G749-53, 1986.

Pohlenz, C.; Buentello, A.; Bakke, A. M. \& Gatlin III, D. M. Free dietary glutamine improves intestinal morphology and increases enterocyte migration rates, but has limited effects on plasma amino acid profile and growth performance of channel catfish Ictalurus punctatus. Aquac., 370-371:32-39, 2012.

Shima, Y.; Tajiri, T.; Taguchi, T. \& Suita, S. Increased expression of c-fos and c-jun in the rat small intestinal epithelium after ischemia-reperfusion injury: a possible correlation with the proliferation or apoptosis of intestinal epithelial cells. J. Pediatr. Surg., 41(4):830-6, 2006.

Syiem, D.; Syngkai, C.; Kharbuli, B.; Kayang, H. \& Khongwir, B. S. Anti-tumor activity of crude root extract of Potentilla fulgens. Indian Drugs, 40:124-5, 2003.

Syiem, D.; Khup, P. Z. \& Syiem, A. B. Effects of Potentilla fulgens Linn. On carbohydrate and lipid profiles in diabetic mice. Pharmacologyonline, 2:78795, 2009.

Tangpu, V.; Deori, K. \& Yadav, A. K. Evaluation of safety and protective effects of Potentilla fulgens root extract in experimentally induced diarrhea in mice. $J$. Intercult. Ethnopharmacol., 3(3):103-8, 2014.

Tunc, T.; Uysal, B.; Atabek, C.; Kesik, V.; Caliskan, B.; Oztas, E.; Ersoz, N.; Oter, S. \& Guven, A. Erdosteine and ebselen as useful agents in intestinal ischemia/ reperfusion injury. J. Surg. Res., 155(2):210-6, 2009.

Correspondence to:

Dr. Nurettin Tunç

Department of Gastroenterology,

Fırat of University, Faculty of Medicine Elazıg

Prof. Dr. Engin Deveci

Department of Histology and Embryology, Faculty of Medicine, Dicle of University

Diyarbakır - TURKEY

Received: 03-02-2015

Email: engindeveci64@gmail.com
Accepted: 21-09-2015 